\title{
Predictors of Urinary Tract Infection and Their Diagnostic Performances among Cameroonian Under-five
}

\author{
Dorgelesse Francine Kouemo Motse ${ }^{1,2}$, Guy Pascal Ngaba ${ }^{1}$, Loick Pradel Kojom ${ }^{3}$, Danielle Christiane \\ Kedy Koum ${ }^{1}$, Cecile Ebongue Okalla ${ }^{1,4}$, Calixte Ida Penda ${ }^{1}$, Evelyn Mah $^{5}$, Andreas Chiabi ${ }^{5}$, Dieudonné \\ Désiré Adiogo ${ }^{1}$ \\ ${ }^{1}$ Department of Biological Science, Faculty of Medicine and Pharmaceutical Science, the University of Douala, \\ Douala, Cameroon \\ ${ }^{2}$ Department of Medical Laboratory Science, Faculty of Health Sciences, University of Buea, Buea, Cameroon \\ ${ }^{3}$ Department of Animal Sciences, Faculty of Science, the University of Douala, Douala, Cameroon \\ ${ }^{4}$ Douala General Hospital, Douala, Cameroon \\ ${ }^{5}$ Department of Pediatrics, Faculty of Medicine and Biomedical Science, University of Yaounde I, Yaounde, \\ Cameroon
}

\begin{abstract}
Objective: Urinary tract infection (UTIs) in child is a serious public health problem especially in developing countries. This study aimed at identifying factors associated with urinary tract infection and determining their diagnosis performances as well as resulting algorithms among Cameroonian under-five.

Methods: A descriptive and analytical cross sectional study took place from May 2013 to March 2014 at Pediatrics Department of the Bonassama District hospital in the town of Douala. Urine samples were collected dependent on the age of children and its aptitude to micturate. Ten microliters $(10 \mu \mathrm{L})$ of urine specimen were cultured at $37^{\circ} \mathrm{C}$ for 24 48 hours. In addition, sociodemographic, anthropometric, clinic and biological information of each child were documented.

Results: The prevalence of UTI was 32.2\% (129/400) which was mainly caused by Escherichia coli (41.1\%). A total of four risk factors for UTI were found after adjustment for all pertinent characteristics of children. These included female gender $(A R R=0.55 ; p=0.0046)$, presence of fever $(A R R=1.83 ; p=0.0426)$, trouble urine $(A R R=1.36 ; p=$ $0.0063)$ and presence of nitrites in urine $(A R R=1.09 ; p=0.0001)$. Presence of nitrites was the most discriminant parameter based on specificity (98.1\%), positive predictive value (95.4\%) and negative predictive value (90.1\%). The diagnosis performances have gradually improved with the increasing number of parameters.

Conclusion: This study reported four factors associated with increased risk for UTI. This also outlined that the presence of nitrites in urine had best diagnosis performances and different predictors-based clinical algorithms could be helpful especially in the identification of UTI-negative children. J Microbiol Infect Dis 2019; 9(2):68-77.
\end{abstract}

Keywords: Under-five, urinary tract infection, predictors, predictive potential, Cameroon

\section{INTRODUCTION}

Urinary tract infections (UTIs) are defined as any infection, commonly of bacterial origin, that occurs in any part of the urinary system [1]. Nowadays, it represents a serious public health problem and is responsible for nearly 150 million disease cases every year worldwide [1].

Urinary tract infections are a common cause of acute illness in infants and children through the world who account for the heaviest burden particularly those aged less than five years [2]. A study of Williams and coworkers highlighted children will have at least one episode of UTI by the age of seven [3].

The epidemiology of UTI in children is still under many investigations in different settings especially on its predictors or determinants. The identification of these is critical as it may be very helpful in medical practice through better management. A few studies addressed the topic and the results have varied with regard to the setting [4-7]. For instance, Festo and colleagues found that factors including female gender, age

Correspondence: Dr. Dorgelesse Francine Kouemo Motse, Faculty of Medicine and Pharmaceutical Science, the University of Douala, P.O. Box 24157, Douala, Cameroon

E-mail: kouemofrancine@yahoo.fr

Received: 28 December 2018 Accepted: 01 June 2019

Copyright (C JMID / Journal of Microbiology and Infectious Diseases 2019, All rights reserved 
$<2$ years, positive white blood cell microscopy, positive nitrite test, diarrhea and prolonged fever, were associated with higher risk for UTI in Tanzanian children [4]. More recently, it was found that female gender and infrequent voiding were increasing the risk for UTI in children and adolescents in Brazil [7].

Besides, the definition of algorithms could be an interesting approach for diagnosing urinary tract infections in our context where urine culture, referred to as the gold standard, either is not always routinely performed in health facilities of developing countries owing its cost [8] or is absent especially in remote areas.

In Cameroon, to the best to our knowledge none study specifically addressed these both issues. Thus, this study aimed at identifying factors associated with urinary tract infection and determining their diagnosis performances as well as resulting algorithms among under-five living in the town of Douala, Cameroon.

\section{METHODS}

\section{Study site}

A descriptive and analytical cross sectional study took place from May 2013 to March 2014 at Pediatrics Department of the Bonassama District hospital in the town of Douala. The description of this hospital and Douala is presented elsewhere [9].

\section{Study population and criteria}

Children aged $<5$ years, having prescription for urine analysis and whose parents/guardians accepted by signing an informed consent form were included in the study.

\section{Sample size}

The sample size was calculated using the Lorentz's formula as follows: $n=z^{2} p(1-p) / d^{2}$ where $\mathrm{n}=$ the required sample size, $\mathrm{Z}=$ statistic for the desired confidence level (1.96), $p=$ assumed prevalence of UTI among under-five and $d=$ accepted margin of error $(5 \%)$. The prevalence of UTI recently was reported by a local study [10]. A minimum sample size of 185 under-five was required for this study.

\section{Questionnaire}

Information regarding gender, age, residence area, weight, antibiotics exposure history and temperature were documented from medical records of each child using structured survey form. In addition, additional information on clinic presentations of each child was documented based on clinic examination done by a pediatrician.

\section{Urine collection}

Prior to urine collection, genital organs of each child were carefully cleaned with alcohol antiseptic solution. Procedures for urine collection were dependent on the age of children and its aptitude to micturate. Mid-stream clean catch urine (MSU) was intended to children able to provide urine without any difficulties. Suprapubic aspiration was used for newborns and children having difficulties to control their micturition. Sterile container was placed in these children for 30 minutes and new containers were placed each 30 minutes up to obtaining urine. In children under catheter, urine samples were obtained by pressing for 30 minutes the tube of catheter and then puncturing accumulated urine up stream with sterile syringe. Urine samples were conveyed to the Laboratory of the Pediatrics Department for further analysis.

\section{Urinalysis}

Urine samples were analyzed based on both macroscopic and microscopic parameters. Macroscopic parameters were focused on color and turbidity of urine while microscopic ones were focused on the presence and quantification of white blood cells (pus cells), red blood cells (RBC), crystals, yeasts, parasites and epithelial cells. Besides, urinary dipstick was used for searching for glucose, nitrites, proteins and hemoglobin.

\section{Culture}

Ten microliters $(10 \mu \mathrm{L})$ of urine specimen were inoculated onto culture media and incubated at $370^{\mathrm{C}}$ for 24-48 hours. Eosin-Methylene Blue (EMB), Cysteine lactose electrolyte deficient agar (CLED), Sabouraud dextrose agar (SDA) and Muller Hinton agar media were used for culture. Results were expressed as number of cells/high power field (HPF). High colony counts with more than one species of microorganisms were considered as contamination. For contaminated culture plates, culture was repeated. Isolates were identified using the API $20 \mathrm{E}$ kit accordance to manufacturer's instructions.

\section{Operational definitions}

A urine sample was considered positive for UTI if a single bacterial organism was cultured at a concentration of $\geq 10^{5} \mathrm{CFU} / \mathrm{mL}$, or when a single organism was cultured at a concentration of $10^{4}$ 
$\mathrm{CFU} / \mathrm{mL}$ and more than 5 leukocytes or erythrocytes per HPF were observed.

Pyuria and haematuria were defined as the presence of more than five leukocytes or erythrocytes per HPF.

\section{Ethical statements}

Ethical agreement was sought from the institutional review boards (IRB) of the University of Douala and Littoral Health Delegation respectively. Informed consent forms explaining the objectives, benefices and risk of the study were issued to parents/guardian of each child for obtaining their assent.

\section{Statistical analysis}

All data were keyed into an Excel spreadsheet and analyzed with statistical package for social science (SPSS) version 16.0 for Windows (SPSS, Inc., Chicago, IL, USA). Qualitative and quantitative variables were presented as percentage (confidence interval at 95\%) and mean \pm standard deviation (SD) respectively. Univariate and multivariate logistic regression models were used to identify predictors for urinary tract infections. The resulting odds ratio $(\mathrm{OR})$ were then converted into risk ratio $(\mathrm{RR})$ as described by [11]. P-value $<0.05$ were considered statistically significant. Predictors of urinary tract infection found in the study have been used for defining diagnosis algorithms and their diagnosis performances were then evaluated. Parameters of diagnosis performances were computed as described by [12]. These consisted of sensitivity (Se), specificity (Sp), positive predictive value (PPV), negative predictive value (NPV), accuracy and kappa index.

\section{RESULTS}

\section{Baseline characteristics of children}

A total of 400 children were included in the study. As presented in Table 1, males accounted for $52.7 \%$ of the children giving a male-to-female ratio of $1.12(211 / 189)$. Children were aged $17 \pm 14$ months on average with those aged 24-60 months representing $28.3 \%$ $(113 / 400)$. Besides, $14 \%$ and $74.5 \%$ of children had history of antibiotic exposure and were collected urine through sterile pot respectively.

\section{Prevalence and germs responsible for} urinary tract infection

In total, 129 of 400 children enrolled in the study were diagnosed with urinary tract infection. Thus, the prevalence of UTI was $32.2 \%(95 \% \mathrm{Cl}$ :
28.6\%-37.8\%). Bacteria (97.8\%, 126/129) were mainly involved in UTI while the $2.2 \%(3 / 129)$ remaining were represented by yeasts. The distribution of UTI-causing bacteria comprised of gram-negative bacteria $(92.9 \%, 117 / 126)$ and gram-positive bacteria (7.1\%, 9/117). Escherichia coli (41.1\%), Enterobacter cloacae $(18.6 \%)$ and Klebsiella pneumoniae (8.5\%) were bacteria most commonly associated with urinary tract infections.

Table 1: Sociodemographic data of participants

\begin{tabular}{|c|c|}
\hline Variables & $\mathbf{N}(\%) /$ mean value \\
\hline \multicolumn{2}{|l|}{ Gender } \\
\hline Female & $189(47.3)$ \\
\hline Male & $211(52.7)$ \\
\hline \multicolumn{2}{|l|}{ Age groups (months) } \\
\hline$[0-6[$ & $66(16.4)$ \\
\hline$[6-12[$ & $116(29.0)$ \\
\hline$[12-24[$ & $105(26.3)$ \\
\hline [24-60] & $113(28.3)$ \\
\hline \multicolumn{2}{|l|}{ Antibiotic exposure history } \\
\hline No & $344(86.0)$ \\
\hline Yes & $56(14.0)$ \\
\hline \multicolumn{2}{|l|}{ Urine collection method } \\
\hline Pot & $298(74.5)$ \\
\hline Sac & $102(25.5)$ \\
\hline Mean age $\pm S D$ (month) & $17 \pm 14$ \\
\hline Mean temperature $\pm \mathrm{SD}\left({ }^{\circ} \mathrm{C}\right)$ & $37.8 \pm 0.9$ \\
\hline Mean weight \pm SD $(\mathrm{kg})$ & $8.8 \pm 3.1$ \\
\hline \multicolumn{2}{|c|}{$\begin{array}{l}\text { Data are presented as frequency (percentage) and mean } \pm \\
\text { standard deviation (SD) }\end{array}$} \\
\hline $\begin{array}{l}\text { Influence of } \\
\text { characteristics on risk fo }\end{array}$ & $\begin{array}{l}\text { ociodemographic } \\
\text { TTI }\end{array}$ \\
\hline
\end{tabular}

As presented in Table 2; gender and age group were associated with risk for urinary tract infection. Male were found to be lesser at risk $(\mathrm{ARR}=0.61 ; 95 \% \mathrm{Cl} 0.43-0.85 ; \mathrm{P}=0.00017)$ than their female counterparts. Likewise, this risk was lower in children aged 24-60 months $(\mathrm{ARR}=0.50 ; 95 \% \mathrm{Cl} \quad 0.27-0.84 ; \mathrm{P}=0.0064)$ compared to those aged 0-6 months.

\section{Influence of anthropometric and clinical characteristics on UTI risk}

The influence of anthropometric and clinical characteristics of children on the risk for UTI is summarized in Table 3 . Two factors namely body weight and presence of fever were significantly associated with urinary tract 
infection. Indeed, any increasing by $1 \mathrm{~kg}$ in body weight was associated with decreasing by $10 \%$ $(\mathrm{ARR}=0.90 ; 95 \% \mathrm{Cl} 0.83-0.97 ; \mathrm{P}=0.0047)$ in the risk for UTI. Likewise, children presenting fever were about twofold (ARR $=1.71 ; 95 \% \mathrm{Cl}$ 1.32-2.22; $P=0.0001$ ) more at risk for developing UTI than their afebrile counterparts (Table 3). It should be noted that the risk for developing UTI was increasing with the number of symptoms presented at admission even though no statistically significant difference was found.

\section{Association Urine collection method, urinalysis and UTI risk}

In both univariate and multivariate logistic regression models urine turbidity and presence of nitrites in urine were associated with higher risk for UTI. In multivariate analysis, this risk was $1.35(95 \% \mathrm{Cl} 1.12-1.42 ; \mathrm{P}=0.0011)$ and 1.09 $(95 \% \mathrm{Cl} 1.08-1.11 ; \mathrm{P}<0.0001)$ times higher in children whose urine was trouble and had nitrites present in urine respectively (Table 4). In addition, the risk for UTI was 1.05 times higher with an increasing by one unity in the count of epithelial cells in univariate analysis.

Influence of demographic profile, clinical profile and urinalysis on UTI risk

A total of four risk factors for UTI were found after adjustment for all pertinent characteristics of children including demographic data, clinical data, urinalysis results and microscopy inspection results. These included female gender $\quad(A R R=0.55 ; 95 \% \mathrm{Cl} \quad 0.44-0.92 ; \quad p=$ $0.0046)$, presence of fever (ARR $=1.83: 95 \% \mathrm{Cl}$ 1.03-2.47; $p=0.0426)$, trouble urine $(A R R=1.36$;
$95 \% \mathrm{Cl} 1.15-1.43 ; \mathrm{p}=0.0063)$ and presence of nitrites in urine $(A R R=1.09 ; 95 \% \mathrm{Cl} 1.01-1.10$; $p=0.0001$ ) as presented in Table 5. Ages of children, quantity of epithelial cells and body weight have revealed to be no longer statistically associated with UTI after adjustment $(P>0.05)$.

\section{Diagnosis performances of associated factors and resulting algorithms}

The results on diagnosis performances of predictors identified in this study and different resulting algorithms are summarized in Table 6. Presence of nitrites was the most discriminant parameter in terms of specificity $(98.1 \%)$, positive predicative value $(95.4 \%)$, negative predictive $(90.1 \%)$ value and accuracy compared to parameters female gender, fever and trouble urine. In addition, children whose urine was found contain nitrites had nearly 42 times (positive LR $=41.65$ ) more chance of having positive culture than children whose urine was nitrites-negative. Besides, we found that the presence of at least one of the four predictors had better diagnosis performances than other defined algorithms. Indeed, this algorithm had highest values of sensitivity $(99.2 \%)$, negative predictive values $(97.0 \%)$ and positive likelihood ratio (8.34). Importantly, the diagnosis performances have gradually improved with the increasing number of parameters. Specificity was passed from $65.3 \%$ to $100 \%$ for two parameters and all parameters respectively. The same trend was observed for PPV and NPV which passed from $33.6 \%$ to $100 \%$ and from $67.3 \%$ to $67.7 \%$ respectively (Table 6 ).

Table 2. Sociodemographic characteristics and urinary tract infection.

\begin{tabular}{|c|c|c|c|c|c|c|}
\hline Factors & $\mathbf{N}$ & UTI-positive n (\%) & RRR (95\%Cl) & P-value & ARR $(95 \% \mathrm{Cl})$ & P-value \\
\hline \multicolumn{7}{|l|}{ Gender } \\
\hline Female & 189 & $74(38.7)$ & 1 & & 1 & \\
\hline Male & 211 & $55(26.3)$ & $0.67(0.49-0.90)$ & $0.0082^{*}$ & $0.61(0.43-0.85)$ & $0.0017^{*}$ \\
\hline \multicolumn{7}{|l|}{ Age $(m)$} \\
\hline$[0-6[$ & 66 & $25(37.9)$ & 1 & & 1 & \\
\hline$[6-12[$ & 116 & $47(40.5)$ & $1.07(0.71-1.48)$ & 0.9128 & $1.02(0.66-1.43)$ & 0.9128 \\
\hline$[12-24[$ & 105 & $32(30.5)$ & $0.81(0.50-1.20)$ & 0.3182 & $0.76(0.45-1.15)$ & 0.2142 \\
\hline [24-60] & 113 & $25(22.1)$ & $0.59(0.34-0.94)$ & $0.0248^{*}$ & $0.50(0.27-0.84)$ & $0.0064^{*}$ \\
\hline
\end{tabular}

$\mathrm{a}=$ Univariate and multivariate logistic regression models were used;

$\mathrm{m}=$ months; $\mathrm{UTI}=$ Urinary tract infection; RRR = Raw Risk ratio; ARR = Adjusted Risk ratio; $95 \% \mathrm{Cl}=$ Confidence interval at $95 \%$ *Significant at $\mathrm{P}$-value $<0.05$ 
Table 3. Anthropometric, clinical characteristics and UTI risk.

\begin{tabular}{|c|c|c|c|c|c|c|}
\hline Factors & $\mathbf{N}$ & $\begin{array}{l}\text { UTI-positive } \\
\text { n (\%) }\end{array}$ & RRR (95\%Cl) & P-value & ARR (95\%Cl) & P-value \\
\hline Weight (Kg) & 400 & l & $0.92(0.85-0.98)$ & $0.0145^{\star}$ & $0.90(0.83-0.97)$ & $0.0047^{\star}$ \\
\hline ATB exposure history, yes (\%) & 56 & $16(28.6)$ & $0.86(0.52-1.32)$ & 0.5259 & $0.99(0.58-1.52)$ & 0.9652 \\
\hline \multicolumn{7}{|c|}{ Number of signs/symptoms presented } \\
\hline None & 7 & $1(85.7)$ & 1 & & 1 & \\
\hline One & 200 & $72(36.0)$ & $1.79(0.51-2.53)$ & 0.2478 & $1.81(0.51-2.62)$ & 0.2645 \\
\hline Two & 139 & $38(27.3)$ & $1.60(0.33-2.14)$ & 0.4441 & $1.68(0.33-3.22)$ & 0.4579 \\
\hline Three & 52 & $16(30.8)$ & $1.78(0.38-2.01)$ & 0.3936 & $1.76(0.38-2.97)$ & 0.3817 \\
\hline Fever, yes (\%) & 313 & $105(33.5)$ & $1.62(1.23-2.06)$ & $0.0001^{*}$ & $1.71(1.32-2.22)$ & $0.0001^{*}$ \\
\hline Diarrhea, yes (\%) & 42 & $16(38.1)$ & $1.18(0.78-1.61)$ & 0.3929 & $1.26(0.80-1.73)$ & 0.2928 \\
\hline Vomiting, yes (\%) & 54 & $14(25.9)$ & $0.76(0.44-1.23)$ & 0.2869 & $0.69(0.37-1.19)$ & 0.2002 \\
\hline Fatigue, yes (\%) & 7 & $1(14.3)$ & $0.38(0.05-2.28)$ & 0.3271 & $0.31(0.03-2.02)$ & 0.2511 \\
\hline Abdominal pain, yes (\%) & 22 & $7(31.8)$ & $0.77(0.10-2.39)$ & 0.7565 & $0.76(0.09-2.44)$ & 0.7524 \\
\hline Convulsions, yes (\%) & 12 & $2(16.7)$ & $0.46(0.10-1.65)$ & 0.2556 & $0.51(0.10-1.95)$ & 0.3594 \\
\hline
\end{tabular}

Table 4. Urine collection method, urinalysis and urinary tract infection.

\begin{tabular}{|c|c|c|c|c|c|c|}
\hline Factors & $\mathbf{N}$ & $\begin{array}{c}\text { UTI-positive } \\
\text { n (\%) }\end{array}$ & RRR (95\%Cl) & P-value & ARR $(95 \% \mathrm{Cl})$ & P-value \\
\hline \multicolumn{7}{|l|}{ Urine collection method } \\
\hline Pot & 298 & $90(30.2)$ & 1 & & 1 & \\
\hline Sac & 102 & $39(38.2)$ & $0.79(0.56-1.07)$ & 0.1351 & $1.12(0.53-1.80)$ & 0.7301 \\
\hline \multicolumn{7}{|l|}{ Urine turbidity } \\
\hline Clear & 374 & $111(29.7)$ & 1 & & 1 & \\
\hline Trouble & 26 & $18(69.2)$ & $1.33(1.21-1.40)$ & $0.0001^{*}$ & $1.35(1.12-1.42)$ & $0.0011^{*}$ \\
\hline \multicolumn{7}{|l|}{ Nitrites } \\
\hline No & 292 & $30(10.3)$ & 1 & & 1 & \\
\hline Yes & 108 & $99(91.7)$ & $1.09(1.07-1.09)$ & $<0.0001^{*}$ & $1.09(1.08-1.11)$ & $<0.0001^{*}$ \\
\hline \multicolumn{7}{|l|}{ Proteinuria } \\
\hline No & 396 & $128(32.3)$ & 1 & & 1 & \\
\hline Yes & 4 & $1(25.0)$ & $0.76(0.09-2.77)$ & 0.7565 & $1.17(0.10-3.49)$ & 0.8785 \\
\hline Quantity of epithelial cells & 400 & l & $1.09(1.04-1.15)$ & $0.0006^{*}$ & $1.05(0.96-1.14)$ & 0.2968 \\
\hline Quantity of yeast & 400 & l & $1.07(0.76-1.52)$ & 0.6833 & $1.32(0.81-2.16)$ & 0.2696 \\
\hline $\mathrm{pH}$ & 400 & 1 & $1.66(0.79-3.48)$ & 0.1779 & $0.87(0.42-1.82)$ & 0.7128 \\
\hline
\end{tabular}


Table 5: Demographic profile, clinical profile, urinalysis, microscopy findings and urinary tract infection

\begin{tabular}{|c|c|c|c|c|}
\hline Factors & $\mathbf{N}$ & $\begin{array}{c}\text { UTI-positive } \\
\text { n (\%) }\end{array}$ & ARR $(95 \% \mathrm{Cl})$ & P-value \\
\hline \multicolumn{5}{|l|}{ Gender } \\
\hline Female & 189 & $74(38.7)$ & 1 & \\
\hline Male & 211 & $55(26.3)$ & $0.55(0.44-0.92)$ & $0.0046^{*}$ \\
\hline \multicolumn{5}{|l|}{ Age (months) } \\
\hline$[0-6[$ & 66 & $25(37.9)$ & 1 & \\
\hline$[6-12[$ & 116 & $47(40.5)$ & $1.75(0.93-2.24)$ & 0.0735 \\
\hline$[12-24[$ & 105 & $32(30.5)$ & $1.39(0.43-2.58)$ & 0.5276 \\
\hline [24-60] & 113 & $25(22.1)$ & $1.11(0.20-3.18)$ & 0.8892 \\
\hline Weight (Kg) & 400 & / & $0.99(0.81-1.22)$ & 0.9288 \\
\hline
\end{tabular}

Number of signs/symptoms presented

\begin{tabular}{|c|c|c|c|c|}
\hline None & 7 & $1(85.7)$ & 1 & \\
\hline One & 200 & $72(36.0)$ & $0.99(0.18-1.16)$ & 0.9569 \\
\hline Two & 139 & $38(27.3)$ & $0.43(0.01-2.90)$ & 0.5416 \\
\hline Three & 52 & $16(30.8)$ & $0.62(0.01-2.90)$ & 0.7245 \\
\hline Fever, yes (\%) & 313 & $105(33.5)$ & $1.83(1.03-2.47)$ & $0.0426^{*}$ \\
\hline Diarrhea, yes (\%) & 42 & $16(38.1)$ & $1.26(0.53-2.01)$ & 0.5417 \\
\hline Vomiting, yes (\%) & 54 & $14(25.9)$ & $0.91(0.29-2.08)$ & 0.8455 \\
\hline Fatigue, yes (\%) & 7 & $1(14.3)$ & $0.32(0.00-6.68)$ & 0.5783 \\
\hline Abdominal pain, yes (\%) & 22 & $7(31.8)$ & $0.76(0.00-3.09)$ & 0.8849 \\
\hline Convulsions, yes (\%) & 12 & $2(16.7)$ & $1.06(0.09-4.50)$ & 0.9588 \\
\hline \multicolumn{5}{|l|}{ Urine collection method } \\
\hline Pot & 298 & $90(30.2)$ & 1 & \\
\hline Sac & 102 & $39(38.2)$ & $1.30(0.73-1.87)$ & 0.3213 \\
\hline \multicolumn{5}{|l|}{ Urine turbidity } \\
\hline Clear & 374 & $111(29.7)$ & 1 & \\
\hline Trouble & 26 & $18(69.2)$ & $1.36(1.15-1.43)$ & $0.0062^{*}$ \\
\hline \multicolumn{5}{|l|}{ Nitrites } \\
\hline No & 292 & $30(10.3)$ & 1 & \\
\hline Yes & 108 & $99(91.7)$ & $1.09(1.01-1.10)$ & $0.0001^{*}$ \\
\hline \multicolumn{5}{|l|}{ Proteinuria } \\
\hline No & 396 & $128(32.3)$ & 1 & \\
\hline Yes & 4 & $1(25.0)$ & $0.35(0.01-2.70)$ & 0.4284 \\
\hline Quantity of epithelial cells & 400 & l & $1.05(0.95-1.16)$ & 0.3336 \\
\hline Quantity of yeast & 400 & l & $1.45(0.90-2.34)$ & 0.1263 \\
\hline $\mathrm{pH}$ & 400 & l & $0.72(0.33-1.57)$ & 0.4105 \\
\hline
\end{tabular}

${ }^{a}$ Univariate and multivariate logistic regression models were used;

$\mathrm{UTI}=$ Urinary tract infection; ARR = Adjusted Risk ratio; $95 \% \mathrm{Cl}=$ Confidence interval at $95 \%$

* Significant at P-value $<0.05$ 
Table 6. Diagnostic performances of UTI-associated factors and resulting algorithms.

\begin{tabular}{|c|c|c|c|c|c|c|c|}
\hline $\begin{array}{l}\text { Performance } \\
\text { parameters }\end{array}$ & $\begin{array}{l}\text { Female } \\
\text { gender }\end{array}$ & $\begin{array}{c}\text { Trouble } \\
\text { urine }\end{array}$ & $\begin{array}{l}\text { Nitrites } \\
\text { present }\end{array}$ & $\begin{array}{l}\text { One out the } \\
\text { parameters }\end{array}$ & $\begin{array}{c}\text { Two out } \\
\text { four parameters }\end{array}$ & $\begin{array}{c}\text { Three out four } \\
\text { parameters }\end{array}$ & $\begin{array}{c}\text { All four } \\
\text { parameters }\end{array}$ \\
\hline Se, $\%(95 \% \mathrm{Cl})$ & $57.6(49.1-65.7) 80.3(72.7-80.3)$ & $13.6(8.8-20.5)$ & $78.0(70.2-84.2)$ & $99.2(95.8-99.9)$ & $35.6(28.0-44.1)$ & $41.7(33.6-50.2)$ & $3.0(1.2-7.5)$ \\
\hline $\mathrm{Sp}, \%(95 \% \mathrm{Cl})$ & $42.9(51.1-62.9) 22.5(17.8-27.8)$ & $97.0(94.2-98.5)$ & $98.1(95.7-99.2)$ & $88.1(83.3-91.4)$ & $65.3(59.4-70.1)$ & $99.3(97.3-99.8)$ & $100(98.6-100)$ \\
\hline PPV, \% (95\%Cl) & 39.8 (33.1 - 46.9)33.9 (28.9 - 39.3) & $69.2(50.0-83.5)$ & $95.4(89.6-98.0)$ & $35.7(31.0-40.7)$ & $33.6(26.3-41.7)$ & $96.5(88.1-99.0)$ & $100(51.0-100)$ \\
\hline NPV, \% $(95 \% \mathrm{Cl})$ & $73.2(66.8-78.8) 69.8(59.4-78.5)$ & $69.5(64.7-74.0)$ & $90.1(86.1-93.0)$ & $97.0(84.7-99.5)$ & $67.3(61.4-72.7)$ & $77.6(72.8-81.7)$ & $67.7(62.9-72.1)$ \\
\hline Positive LR & 1.41 & 0.24 & 41.65 & 8.34 & 1.03 & 59.57 & NA \\
\hline Negative LR & 0.46 & 2.01 & 0.22 & 0.009 & 0.99 & 0.59 & 0.97 \\
\hline
\end{tabular}

Accuracy, \% (95\%Cl) $57.3(52.4$ - 62.0) 41.5 (36.8 - 46.4) $69.5(64.8$ - 73.8) $91.5(88.4$ - 93.9) $40.8(36.0-45.5) \quad 48.0(43.2$ - 52.9$) \quad 80.3(76.1$ - 83.9$) \quad 68.0(63.3$ - 72.4$)$

$\begin{array}{lllllll}\text { Kappa index (SE) } & 0.13(0.05) & 0.02(0.03) & 0.13(0.04) & 0.80(0.03) & 0.08(0.02) & 0.009(0.05)\end{array} \quad 0.48(0.05) \quad 0.04(0.02)$

Se= Sensitivity; Sp = Specificity; PPV = Positive predictive value; NPV = Negative predictive value; LR = Likelihood ratio; SE = Standard error; 95\%Cl = Confidence interval at 95\%; NA = Not available 


\section{DISCUSSION}

Thus, this study aimed to identify predictors of urinary tract infection and assess their diagnosis performances as well as of resulting algorithms among under-five admitted at the Bonassama District hospital of the town of Douala, Cameroon. A total of four factors were found to be independently associated risk for UTI namely gender, fever, urine aspect and presence of nitrites.

Females were more at risk for UTI compared to male and this agrees with many previous studies $[4,5,7]$. This is owed to anatomical peculiarities present in females namely a shorter urethra and its proximity to the anal region. These both enhance the scope for the pathogens to colonize the bladder and accordingly increase the risk for lower urinary tract infections. Also, Saeed and colleagues pointed out the infrequent micturition in girls may also increase the risk of bacterial colonization and consequently infection of the bladder [13]. In addition, it was showed that if a female patient presents to a health facility with the UTI-related typical symptoms, the probability of UTI is comprised between $50 \%-80 \%$ [14].

Fever was associated with increased risk of UTI. This is consistent with previous reports in Africa [5]. In addition, it was outlined that infants with a fever for 48 hours without another source or fever on examination were highly at risk for having UTI [15]. Some pathophysiological pathways underlying the link between the infection and fever have been proposed. Spencer and colleagues pointed out the influence of toll-like receptors (TLRs) in the genesis of UTI-related fever among the patients diagnosed with pyelonephritis. Indeed, these receptors have the ability to recognize uropathogens and then to be activated. Their activation results in the mobilization of several signalling pathways which elicit a strong immune response through the expression of molecules including inflammatory cytokines responsible for fever [16]. Besides, we found fever had low positive predictive value as germ culture might confirm UTI in only $39.8 \%$ of feverous children. This finding emphasizes the fact that fever is not a pathognomonic clinical sign of UTI since many infectious diseases especially malaria can also elicit fever [17]. To be noted, Msaki and colleagues found $11.5 \%$ of UTI-positive children were co-infected with malaria parasites [5].

Trouble urine was the third risk factor for UTI found in the present study. This may be owed to the presence of leucocytes, epithelial cells and yeast found in this study. The presence of its element may indicate urinary tract infection [18]. It should be noted that urine colour can be changed by food and medications especially antibiotics such as metronidazole which has been reported in this study among antibiotics taken by children [19] as well as under physiological conditions. This can explain why a low value of sensitivity (13.6\%) and positive predictive $(69.2 \%)$ were found in this study confirming that this parameter is not very helpful in diagnosis of UTI.

Lastly, presence of nitrites was also associated with increasing in risk for UTI. Nitrites are the products of the activity of nitrate reductase, an enzyme produced by many bacterial species [20]. In addition, most bacteria found commonly involved in UTI in the present study were gramnegative mainly represented by Escherichia coli. This group of bacteria; particularly $E$. coli, contain an enzyme called urease which acidifies the urine leading to the creation of nitrites [21, 22]. Unless urinary tract infection exists these nitrites and other related products are normally not present in urine of healthy individuals. This may explain the highest values of positive (PPV, 95.4\%) and negative (NPV, 90.1\%) predictive values found with this parameter. Our finding is similar to report by Festo et al. [4] who found that nitrite test had a positive predictive value of $86.5 \%$ among Tanzanian children. Thus, this study confirms that the presence of nitrites in urine from children might adequately to be used as good preliminary surrogate of UTI before performing urine culture when it is available. However, it should be outlined that the absence of nitrites in urine necessarily does not the absence of UTI given some bacterial uropathogens nitrate reductase-deficient [23].

Importantly, we found that the diagnosis performances, in terms of PPV and NPV, were gradually improved when these four diagnosis parameters were combined. PPV is passed from $33.6 \%$ to $100 \%$ for two parameters and all parameters respectively. The same trend was observed for NVP which passed from $67.3 \%$ to 
$67.7 \%$. This finding outlines the fact that combination of many parameters referred to as clinical algorithm should be greatly helpful in making decision to evaluate UTI [4] especially in their ability to diagnose children who are really negative for UTI. However, the diagnosis performances of different clinical algorithms presented in this study are mitigated regarding UTI-positive children because of error rates ranging from $0.8 \%-97.0 \%(\mathrm{Se}=3.0 \%-99.2 \%)$.

This study has some limitations. First, all factors which may influence the risk for UTI were not included in this study especially host genetic factors which strongly modulate immune response to uropathogens $[24,25]$. Second, findings of this study provide from one health facility only and could not exactly mirror the pattern in general population. However, the study is the first of its kind that addressed this topic in under-five in Cameroon.

\section{Conclusion}

This study reported four factors associated with increased risk for UTI. This also outlined that the presence of nitrites in urine had best diagnosis performances and different predictors-based clinical algorithms could be helpful especially in the identification of UTI-negative children. However, further studies are needed to confirm our findings.

\section{ACKNOWLEDGMENTS}

They authors are grateful to the children who participated in the study as well as their parents/guardians. We would also like to thank the officials of Bonassama District Hospital.

Conflict Interest: The authors declare that they have no conflict of interest.

\section{Funding source: Not declared REFERENCES}

1. Dibua UME, Onyemerela IS, Nweze El. Frequency, urinalysis and susceptibility profile of pathogens causing urinary tract infections in Enugu State, southeast, Nigeria. Rev Inst Med Trop Sao Paulo 2014; 56(1):55-59.

2. Robinson JL, Finlay JC, Lang ME, Bortolusi R, and Canadian Paediatric Society, Infectious Diseases and Immunization Committee, Community Paediatrics Committee. Urinary tract infections in infants and children: Diagnosis and management. Paediatr Child Health 2014; 19(6):315-319.
3. Williams GJ, Craig JC. Long-term antibiotics for preventing recurrent urinary tract infection in children. Cochrane Database Syst Rev 2006; (3):CD001534

4. Festo E, Kidenya BR, Hokororo A et al. 2011. Predictors of Urinary tract infection among febrile children attending at Bugando Medical Centre Northwestern, Tanzania. Arch Clin Microbiol 2011; 5 (2): 1-7.

5. Msaki BP, Mshana SE, Hokororo A. Prevalence and predictors of urinary tract infection and severe malaria among febrile children attending Makongoro health centre in Mwanza city, North-Western Tanzania. Arch Public Health 2012; 70 (1):4.

6. Anígilájé EA, Bitto TT. Prevalence and predictors of urinary tract infections among children with cerebral palsy in Makurdi, Nigeria. Open J Pediatr 2013; 3: 350-357.

7. Gondim R, Azevedo R, Braga AANM, Veiga ML, Barroso Jr U. Risk factors for urinary tract infection in children with urinary urgency. Int Braz $\mathrm{J}$ Urol 2018; 44 (2): 378-83.

8. Akoachere J-FTK, Suylika Y, Akum N, Seraphine EN. Etiologic profile and antimicrobial susceptibility of community-acquired urinary tract infection in two Cameroonian towns. BMC Res Notes 2012; 5: 21934.

9. Kouemo MDF. Profil de sensibilité des germes responsables d'infection du tractus génital chez des enfants de 5 ans à l'hôpital de District de Bonassama. Mémoire de Master II, Biologie Clinique, Faculté de Médecine et des Sciences Pharmaceutiques, Université de Douala, Cameroun: $75 \mathrm{p}$ [French].

10. Tchendjou Takam PY (2002). L'infection urinaire du nouveau-né et de l'enfant à l'hôpital général de Yaoundé: Aspects cliniques, biologiques, thérapeutiques et évolutifs (Thèse de Médecine). Yaoundé: Université de Yaoundé I. [French].

11. Zhang J, Yu KF. What's the relative risk? A method of correcting the odds ratio in cohort studies of common outcomes. JAMA 1998; 280(19):16901691.

12. Kamgain LM, Assam-Assam J-P, Kojom Foko LP, Kamga Fouamno HL. Prevalence of Malaria Infection and Reliability of ACCUCARE One Step Malaria Test ${ }^{\circ}$ for Diagnosing Malaria in People Living with Human Immunodeficiency Virus Infection in Cameroon. Int J Trop Dis Health 2017; 21 (2): 110.

13. Saeed CH, AL-Otraqchi Kamal IB, Mansoor Isam $Y$. Prevalence of urinary tract infections and antibiotics susceptibility pattern among infants and young children in Erbil city. Zanco J Med Sci 2014; 19 (1): 915-22.

14. Schmiemann Gg, Kniehl E, Gebhardt K, Matejczyk MM, Hummers-Pradier E. The diagnosis 
of urinary tract infection. Dtsch Arztebl Int 2010; 107(21): 361-367.

15. Whiting $\mathrm{P}$, Westwood $\mathrm{M}$, Watt $\mathrm{I}$, Cooper J, Kleijnen J. Rapid tests and urine sampling techniques for the diagnosis of urinary tract infection (UTI) in children under five years: A systematic review. BMC Pediatr 2005; 5(1):4.

16. Spencer JD, Schaderer AL, Becknell B, Watson J, Hains DS. The innate immune response during urinary tract infection and pyelonephritis. Pediatr Nephrol 2014; 29(7): 1139-1149.

17. WHO. World Malaria Report 2017. The World Health Organization, 2017, Geneva, Switzerland: 196 p. Available at URL: www.who.int accessed on 02 August 2018

18. Liao JC, Churchill BM. Pediatric urine testing. Pediatric Clinics of North America 2001; 48(6): 1425-1441.

19. Revollo JY, Lowder JC, Pierce AS, Twilla JD. Urine discoloration associated with Metronidazole: a rare occurrence. J Pharm Technol 2014; 30(2): 5446.

20. Oyaert M, Meensel BV, Cartuyvels R, et al. Laboratory diagnosis of urinary tract infections: Towards a BILULU consensus guidelines. J Microbiol Methods 2018; 146: 92-99.

21. Tiso M, Schechter AN. Nitrate Reduction to Nitrite, Nitric Oxide and Ammonia by Gut Bacteria under Physiological Conditions. PLoS ONE 2015; 10(3): e0119712.

22. Konieczna I, Żarnowiec $\mathrm{P}$, Kwinkowski M, et al. Bacterial Urease and its Role in Long-Lasting Human Diseases. Curr Protein Pept Sci 2012; 13(8): 789-806.

23. Franz M, Horl WH. Common errors in diagnosis and management of urinary tract infection. I: Pathophysiology and diagnostic technique. Nephrol Dial Transplant 1999; 14 (11): 2746-2753.

24. Godaly G, Ambite I, Svanborg C. Innate immunity and genetic determinants of urinary tract infection susceptibility. Curr Opin Infect Dis 2015; 28(1):8896.

25. Koves B, Wullt B. The roles of the host and the pathogen in urinary tract infections. Eur Urol Suppl 2016; 15(4): 88-94. 